\title{
Reseña del libro: "Editando genes: recorta, pega y colorea Las maravillosas herramientas CRISPR"
}

\author{
Autor: Lluís Montoliu \\ Next door publishers | Año 2019 | ISBN 978-84-120685-9-7 | DEPÓSITO LEGAL: DL NA 180-2020
}

El ácido desoxirribonucleico o ADN es considerado la molécula de la vida, es una estructura en forma de doble hélice conformada principalmente por moléculas Ilamadas nucleótidos. Existen 4 tipos de nucleótidos que conforman el ADN; Adenina (A), Timina (T), Guanina (G) y Citocina (C), la combinación de estas cuatro "letras" da lugar a un código que otorga características únicas a los seres vivos. ¿Este código puede sufrir cambios?, ¿es posible inducir cambios en el ADN para nuestro beneficio?

En la actualidad, cuando hablamos de mejoramiento o modificaciones genéticas podemos asociarlo con que es una tecnología novedosa, sin embargo, si observamos tiempo atrás podemos percatarnos de que los seres humanos hemos intervenido en la genética desde hace miles de años, al hacer cruces entre plantas o animales para obtener aquellos con las características más beneficiosas. La modificación genética en la que intervenimos activamente sobre los individuos surgió a partir de los años 50, tras la inducción de cambios o mutaciones en el ADN de las plantas al ser expuestas a agentes mutagénicos como la radiación, sin embargo, solo podía esperarse que los cambios introducidos al azar fueran beneficiosos para el individuo. No es hasta hace unos años que tenemos las herramientas capaces de modificar genéticamente un organismo con una precisión nunca vista. En este libro se habla precisamente de las ultimas herramientas descubiertas para la edición genética, las CRISPR (clustered regularly interspaced short palindromic repeats).

El autor, Lluís Montoliu (Investigador del centro nacional de biotecnología de España) plasma en este libro todo lo correspondiente a las herramientas CRISPR de edición genética de manera técnica y sencilla, desde su descubrimiento, como funcionan, sus aplicaciones en el área biotecnológica y de la salud, conflictos de patentes y propiedad intelectual, hasta las posibles implicaciones éticas y sociales derivadas de su aplicación.

El autor inicia este libro con un prólogo escrito por el mismo Francis Mojica (Investigador de la universidad de alicante) quien es considerado como el padre de las herramientas CRISPR. En los años 90, Mojica trabajaba en su tesis doctoral estudiando el genoma de unas arqueas capaces de

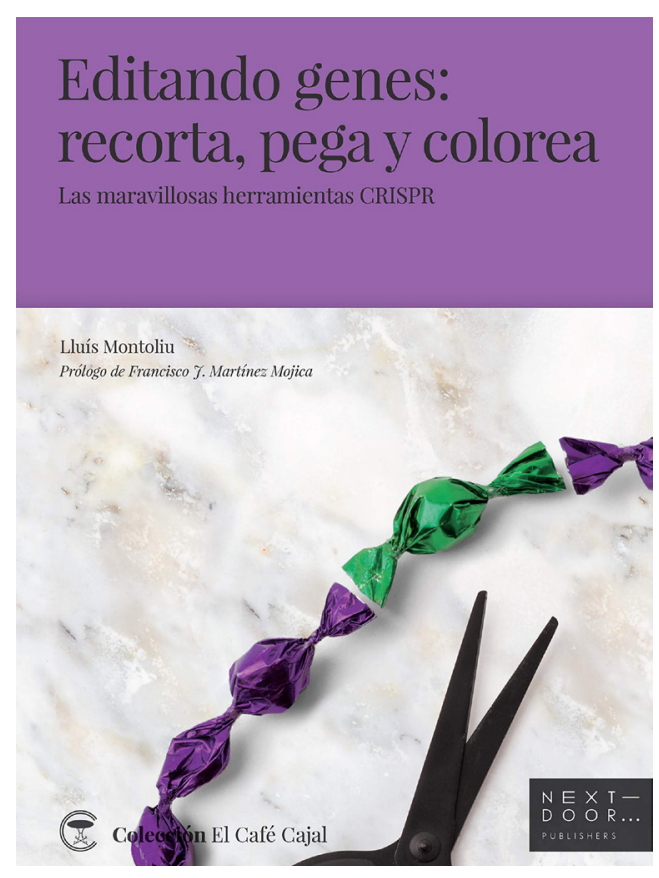


sobrevivir a las altas concentraciones de sal en las salinas de Santa Pola (Alicante). Ahí, a través de los populares métodos de secuenciación de la época, descubrió que estas arqueas poseían secuencias repetidas de ADN que aparecían a intervalos regulares, sin embargo, esta no era la primera vez que se describían estas secuencias, anteriormente habían sido descritas también en bacterias como Escherichia coli y Mycobacterium tuberculosis. Años después, pese al rechazo de muchas revistas de prestigio, Mojica publicaría lo que sería quizá uno de sus artículos más importantes, donde postularía que estas repeticiones forman parte de un sistema de defensa de bacterias y arqueas contra los virus y que sentaría las bases para el desarrollo de la herramienta de edición genética CRISPR-cas.

Desde el título del libro, el autor nos da un indicio de lo que es capaz de realizar el sistema CRISPR-cas, al reconocer y "recortar" una secuencia de ADN justo en el lugar de interés que se desea editar, y utilizar el sistema de reparación propio de la célula para "pegar" el corte realizado introduciendo letras o secuencias nuevas que nos permitan obtener el cambio que deseamos. Es tal la capacidad de adaptar estas herramientas a nuestras necesidades, que podemos "colorear" las secuencias de ADN de interés al incorporar señales fluorescentes a las herramientas CRISPR y así facilitar su estudio.

¿Qué aplicaciones tangibles se han desarrollado con estas herramientas?, el autor nos da ejemplos de aplicaciones y sistemas novedosos que se han elaborado utilizando CRISPR, principalmente, en el área de la biotecnología y la biomedicina. Por ejemplo, la creación de ratones avatar; estos son modelos de ratón que reproducen la enfermedad de una persona al introducir en el roedor exactamente la misma mutación que presenta el enfermo, esto permite el estudio de padecimientos genéticos de una manera mas precisa, que pudiera traducirse en tratamientos innovadores y personalizados.

Otra gran aplicación biotecnológica, que es quizá una de las más importantes y lucrativas es la relacionada con el sector de producción de alimentos destinados al consumo humano o animal. Los alimentos modificados genéticamente o transgénicos son aquellos en los que se introducen genes o construcción génicas que le otorgan características especiales, sin embargo, han generado conflicto entre grupos opositores que aseguran que este tipo de alimentos producen daños a la salud, aunque no es una aseveración científicamente comprobada. Con el aumento extremadamente rápido de la población es necesario voltear a ver a estas tecnologías que permiten el desarrollo de alimentos que estén mejor adaptados y aprovechen los recursos disponibles, aumentando su calidad y rendimiento.
El autor culmina con lo que es quizá la parte mas importante de este tema, las implicaciones éticas. ¿Qué es lo que podemos y no podemos hacer?, ¿las necesidades en cuestión de tecnología y salud justifican la edición genética?, ¿se podrían utilizar estas nuevas tecnologías no solo para curar, sino, para mejorar al ser humano? Actualmente, se han creado comités como la ARRIGE (Association for Responbile Research and Innovation in Gemone Editing) que buscan dar respuesta a todas estas interrogantes y promover el uso ético de estas técnicas de edición genética.

Editando genes: recorta, pega y colorea resulta un libro imprescindible para cualquiera que quiera introducirse al tema de edición de genes y su herramienta mas importante hasta la fecha. Sin duda, con el tiempo se descubrirán nuevas técnicas que permitan la modificación de genes con mayor eficacia y precisión que las CRISPR, que conviertan a la edición genética en una herramienta imprescindible para el avance de la ciencia. 